\title{
Instituições e Políticas Industriais e Tecnológicas: Reflexões a Partir da Experiência Brasileira
}

\author{
- Wilson Suzigan* \\ - João Furtado**
}

\begin{abstract}
Resumo
Tomando por base as instituições e as políticas industriais e tecnológicas brasileiras, e tendo como referência algumas experiências internacionais bem-sucedidas, este artigo investiga as razões pelas quais, mesmo quando bem formuladas, as políticas industriais e tecnológicas enfrentam problemas de implementação em países que buscam se emparelhar, em termos industriais e tecnológicos, às economias líderes. Os resultados mostram que grande parte dos problemas decorre do "envelhecimento" das instituições, aprisionadas por práticas antigas de fazer políticas, e do seu enfraquecimento - político e financeiro - comparativamente às instituições de política macroeconômica, sugerindo a necessidade de reforma das instituições. Essa reforma, entretanto, teria de superar obstáculos técnicos e, sobretudo, políticos.
\end{abstract}

\section{Palavras-Chave}

indústria, tecnologia, instituições, política industrial, política tecnológica

\begin{abstract}
On the basis of Brazilian institutions and policies for industry and technology, and taking as reference some successful international experiences, this paper investigates the reasons why, even when they are well formulated, industrial and technology policies face serious implementation problems in countries that are trying to catch up with the leading industrial economies. The results show that most of the problems are related to the "aging" of institutions, which are locked into old practices of policy-making, and also to the weakening of their political and financial position vis-à-vis macroeconomic policy institutions. The paper suggests the need of an institutional reform, although recognizing that such reform faces difficult technical and above all political obstacles.
\end{abstract}

\section{Keywords}

industry, technology, institutions, industrial policy, technology policy

\section{JEL Classification}

L52, O14, O38

\footnotetext{
* Departamento de Política Científica e Tecnológica, Instituto de Geociências, Unicamp. Endereço para contato: Unicamp - DPCT-IG/Unicamp - Caixa Postal 6152. CEP:13083-970. Campinas - SP. E-mail: wsuzigan@ige.unicamp.br.

* Departamento de Engenharia da Produção, Escola Polítécnica, USP. E-mail: joao1960@gmail.com.

(Recebido em abril de 2008. Aceito para publicação em maio de 2009).
} 


\section{Introdução}

Este artigo investiga as razões pelas quais, mesmo quando bem formuladas, as políticas industriais e tecnológicas encontram dificuldades de implementação em países que buscam se emparelhar aos países líderes em termos industriais e tecnológicos. Para isso, baseia-se na experiência do Brasil, porém aduzindo elementos de comparação a partir de alguns casos relevantes da recente experiência internacional.

Basear-se na experiência do Brasil é justificável não apenas por esse país ter tido uma longa trajetória histórica de práticas de políticas industriais, mas também pelo fato de ter experimentado, no período recente (anos 1980 em diante), frustrações em várias tentativas de implementar políticas industriais e tecnológicas. Essas frustrações têm sido causadas, em grande medida, por problemas relacionados com a organização institucional da área. Prevalece um razoável consenso de que essa organização institucional necessita de reforma; que essa reforma é tarefa que apresenta enormes dificuldades, e que a questão central a ser resolvida é a da coordenação.

A ineficácia da organização institucional para implementar uma política industrial e tecnológica no Brasil decorre, em parte, de sua extrema complexidade: um número excessivo de órgãos com precária capacidade de mobilizar recursos, administrando instrumentos dispersos e desarticulados, e com poucos quadros técnicos com formação adequada. Decorre também, talvez em maior parte, do "envelhecimento" das instituições, aprisionadas por práticas antigas de fazer políticas. Muitas instituições são remanescentes, e mantêm as mesmas práticas, da organização institucional construída ao longo do período do pós-guerra, em que a política industrial buscava internalizar setores sob um regime de forte proteção, subsídios e decisões centralizadas. Hoje o mundo da indústria é outro: economia aberta, competição internacional, foco em inovação, uso intensivo de conhecimento, agilidade decisória, pronta implementação. As instituições de política macroeconômica e o marco regulatório evoluíram de forma coerente com o novo quadro da economia mundial, mas as instituições da área de indústria e tecnologia pouco se renovaram. Aquelas ganharam status e poder, estas se enfraqueceram, subjugadas e desaparelhadas. Sua reforma é imperativa para que possam atuar de modo eficaz na execução da política industrial e tecnológica.

Essa reforma das instituições, no entanto, esbarra em dificuldades de natureza técnica e política. Tecnicamente, é necessário dotar as instituições de uma visão moderna de política industrial, bem como de funções claramente definidas no sistema institucional da área, instrumentos e recursos adequados, e um quadro técnico estável, bem treinado e qualificado para as respectivas funções. Esta é uma tarefa complexa, tendo em vista o amplo escopo da política industrial e tecnológica e 
a diversidade de instituições e funções. Mas a dificuldade maior é sem dúvida a de natureza política. Muitas instituições tornaram-se objeto de acordos políticos, desvirtuando suas funções. São também comumente capturadas por interesses burocráticos ou corporativistas que resistem a qualquer proposta de reforma, mesmo quando os resultados das suas ações estão em descompasso flagrante com os seus esforços.

Entretanto, a questão central para a gestão da política industrial e tecnológica é a da coordenação das ações governamentais em articulação com o setor privado, protagonista maior dessa política. Sem dúvida, definir a instituição coordenadora é a tarefa mais complexa: que tipo de instituição, com quais poderes, em que posição no organograma federal, com que mecanismos de articulação com o setor privado e com outras áreas de políticas, sobretudo macroeconômica, regional e de comércio exterior. Evidentemente, existe uma forte dependência recíproca entre os macroobjetivos da política industrial e as suas instituições e formas típicas de atuação.

Problemas semelhantes existem em outros países da América Latina e do Caribe, como exposto por Peres (2005). Por isso, acreditamos que a discussão a seguir, baseada no caso do Brasil, seja útil como método para avaliar a eficácia da organização institucional na implementação da política industrial nos países da região. Esse é o tema das próximas sessões. Antes, porém, faz-se uma breve revisão dos elementos teóricos que fundamentam essa discussão.

\section{Fundamentos para Análise das Instituições e das Políticas Industriais}

Instituições e políticas públicas têm desempenhado papel central no desenvolvimento industrial, tanto historicamente quanto nos casos mais recentes de catching up tecnológico. As evidências empíricas são abundantes, mas há também argumentos teóricos, notadamente aqueles derivados das contribuições de autores neoschumpeterianos e da economia evolucionária. Nesta seção buscamos recuperar, brevemente, alguns desses argumentos, primeiro quanto às instituições: definição, relação com o desenvolvimento econômico e processo de mudança, e depois quanto à política industrial: conceito, abrangência e coordenação.

Em trabalho recente, Richard Nelson, ao responder à própria indagação sobre o que são instituições, pondera que há várias concepções que as entendem seja como as regras básicas do jogo (D. North), ou como estruturas de governança (O. Williamson), ou ainda como costumes e padrões usuais de comportamento em contextos específicos (T. Veblen; G. Hodgson), o que constitui um conjunto muito heterogêneo de coisas que dificultam um entendimento adequado do que seja o "bestiário 'ins- 
tituições'” (NELSON, 2006, p. 5-6). Por isso, contrapondo-se à postura de orientação macroeconômica de que basta ter as "instituições certas" ou estabelecer as "regras do jogo", assume a posição de que uma concepção mais útil sobre o que são instituições abrangeria uma grande variedade de coisas diferentes em diferentes contextos analíticos, mas com foco definido pelo que as instituições fazem. Nesse sentido, propõe o conceito de tecnologia social, que se distingue do de tecnologia física da mesma forma em que, numa receita de bolo, a receita seria a tecnologia física, e a maneira como o trabalho é organizado e coordenado para fazer o bolo seria a tecnologia social. Nesta, o termo "tecnologia" indica comportamentos que têm o propósito de fazer com que alguma coisa seja realizada, e o termo "social" significa que esses comportamentos envolvem (ou respondem a ações de) múltiplos agentes (ibidem, p. 11-13). As tecnologias sociais que prevalecem em cada contexto são sustentadas por condicionantes mais gerais, dados pelas chamadas regras do jogo, assim como por estruturas e mecanismos de governo, modos usuais de efetuar transações e interações, e instituições não-mercado, inclusive políticas e instituições específicas a indústrias ou tecnologias. ${ }^{1}$ Nelson (ibidem, p.16) ressalta que "cada tecnologia social envolve estruturas de governo específicas e leis particulares. Algumas oferecem o contexto no qual tecnologias sociais específicas evoluem. Outras mudam como parte essencial do processo evolucionário". Ressalta ainda que, em muitos casos, novas instituições significam novas maneiras de fazer coisas.

Prosseguindo nessa linha, ao discutir a relação entre instituições e crescimento econômico, entendido este como um processo evolucionário impulsionado por inovações, Nelson (ibidem, p. 19-20) deixa claro que esse processo implica uma "destruição criadora" de velhas maneiras de fazer coisas, e, geralmente, de agentes econômicos que eram bons naquelas velhas maneiras, mas não conseguem ou são lentos para adaptar-se às novas. Por isso, afirma que as contínuas interações que sustentam a inovação necessitam de instituições específicas, e que a mudança institucional é parte integrante dos processos de desenvolvimento econômico. No decorrer desses processos surgem novas formas de organização das empresas e novas atividades, enquanto outras desaparecem; surgem, também, novas formas de instituições não-mercado, ${ }^{2}$ novas profissões, novas leis. Tudo isso, segundo Nelson, é mudança institucional. Nessa linha, argumenta que o crescimento econômico impulsionado por inovação deve ser entendido como envolvendo a coevolução de tecnologias e instituições, e que "a dinâmica da mudança institucional deve ser vista por esse ângulo" (ibidem, p. 21-22).

1 Ver também, nesse aspecto, o excelente artigo de Cimoli et al. (2007).

2 Refere-se ao papel de universidades e institutos de pesquisas, de programas governamentais de $\mathrm{P} \& \mathrm{D}$, entre outros. 
Por fim, e especialmente importante do ponto de vista deste trabalho, Nelson argumenta que o processo de mudança institucional constitui um desafio muito mais difícil de ser enfrentado do que o catching up em tecnologias físicas. As tecnologias sociais e instituições relacionadas evoluem num processo errático, em comparação com a evolução das tecnologias físicas. Em suas palavras, "a mudança institucional (...) é muito mais difícil de conduzir e controlar do que a mudança tecnológica e, assim, frequentemente as instituições predominantes constituem barreiras à produtividade e ao progresso econômico" (ibidem, p.8). Tecnologias sociais já estabelecidas e as instituições que as sustentam tendem a resistir a mudanças, mesmo que não estejam cumprindo o papel que delas se espera. Por isso, uma reforma institucional pode ser orientada tanto por ideologia quanto por um correto entendimento dos problemas reais que afetam as instituições que prevalecem (ibidem, p.36-37).

É importante frisar, porém, que ao final do seu trabalho Nelson ressalva que não há uma receita de aplicação geral, podendo haver diferentes arranjos institucionais em diferentes contextos. O que funciona num país pode não funcionar em outro, e talvez se deva acrescentar que o que funcionou em determinada época da história do desenvolvimento industrial de um país pode não funcionar no presente. Os detalhes de cada caso são difíceis de discernir, o que dificulta qualquer análise normativa sobre reformas institucionais. ${ }^{3}$ Essa ressalva é particularmente relevante para os países da América Latina, entre os quais há enormes diferenças em termos de grau de desenvolvimento industrial, padrões de industrialização, arranjos institucionais e contextos políticos e de política econômica.

Quanto à política industrial, de forma coerente com a abordagem de Nelson sobre instituições, este trabalho adota o enfoque de autores neoschumpeterianos e de economia evolucionária. Em contraste com a corrente principal da teoria econômica, que admite fazer políticas industriais apenas para corrigir falhas de mercado, os autores neoschumpeterianos e evolucionários têm uma visão que se poderia dizer mais próxima do mundo real, fundamentada em evidência empírica. Para eles, política industrial é muito mais do que corrigir falhas de mercado ${ }^{4}$, e a implementação dessa política requer o envolvimento de instituições em sentido amplo, inclusive instituições específicas a indústrias, tecnologias e organizações não-mercado, atuando articuladamente e de forma sistêmica, e com algum mecanismo de coordenação.

Esse enfoque toma por base uma rigorosa observação dos fenômenos econômicos que, segundo Nelson e Winter (1982), constitui o que denominam teoria aprecia-

3 Nelson resume esse dilema com o conhecido refrão de que "o diabo está nos detalhes" (ibidem, p. 44).

4 Cimoli et al. (op. cit., p. 58) consideram que falha de mercado é um ponto de partida enganoso para se pensar em política industrial, e afirmam que, quando julgado pelos cânones da análise convencional, "o mundo todo pode ser encarado como uma enorme falha de mercado!". 
tiva. Combinada com a visão Schumpeteriana do papel estratégico da inovação no desenvolvimento econômico, essa teoria descarta o pressuposto do equilíbrio e, sob hipóteses realistas de que o comportamento dos agentes econômicos baseia-se em racionalidade limitada (ou condicionada) e que o conhecimento é predominantemente tácito e idiossincrático, admite que tecnologias, estruturas industriais, formas de organização das empresas e instituições coevoluem, tendo a inovação como força motora. ${ }^{5}$ Nessas condições, a política industrial não deve ser apenas reativa a falhas de mercado e sim ativa, abrangente, direcionada a setores ou atividades industriais indutoras de mudança tecnológica e também ao ambiente econômico e institucional como um todo, que condiciona a coevolução das estruturas de empresas e indústrias e da organização institucional, inclusive a formação de um sistema nacional de inovação. Com isso a política industrial pode criar condições favoráveis ao desenvolvimento econômico liderado pela indústria e impulsionado por inovação.

Isto implica compatibilizar objetivos, metas e instrumentos de política industrial e tecnológica entre si e com a política macroeconômica e investimentos em infraestrutura econômica e social. Esse é um desafio monumental, que poucos países enfrentaram com sucesso ${ }^{6}$, e que depende essencialmente de comando político e capacidade de coordenação da organização institucional.

A questão política desdobra-se em duas: em primeiro lugar, e acima de tudo, a adoção de uma política industrial como estratégia de desenvolvimento deve ser objeto de decisão política. Em segundo lugar, a estratégia deve ser comandada por uma liderança política incontestável. Rodrik (2004, p. 19-20) sugere que seja um ministro de Estado, o vice-presidente ou mesmo o próprio presidente da República. Isto colocaria a política industrial no vértice da política econômica, asseguraria a articulação das instituições executoras e possibilitaria melhor coordenação das ações.

A coordenação, por sua vez, está na essência da política industrial, em contraposição à coordenação descentralizada pelos mecanismos de mercado. Nesta última, medidas de política industrial seriam uma forma de coordenação ex post, em reação a falhas ou imperfeições de mercado. Esse modelo normativo não dá conta dos fenômenos que caracterizam o mundo dinâmico da mudança tecnológica. Nesse mundo dinâmico, os fatores institucionais em sentido amplo (instituições e políticas) parecem moldar a constituição de regras de comportamento, processos de aprendizado, padrões de seleção ambiental, condições contextuais sob as quais os mecanismos econômicos operam - em geral, e principalmente em relação à mudança tecnológica. (DOSI, 1988, p. 138).

5 Ver Nelson e Winter (op. cit.), Possas (1996), Dosi (1988), Dosi e Kogut (1993), e Nelson (1993).

6 Entre outros, o Japão no pós-guerra e a Coreia do Sul a partir dos anos 1960. Sobre o Japão, consultar Johnson (1982) e Odagiri e Goto (1993). O caso coreano foi magistralmente analisado por Kim (1993 e 2005). 
Portanto, a política industrial, no enfoque neoschumpeteriano-evolucionista, é essencialmente uma forma de coordenação ex ante.

Há duas observações importantes sobre essa forma de coordenação por meio da política industrial: primeiro, é uma colaboração estratégica entre governo, empresas e entidades do setor privado tendo em vista objetivos e metas da política industrial, e não uma coordenação centralizada no Estado. Segundo, implica criar instituições específicas, com formato de órgãos colegiados, como instâncias consultivas, deliberativas e decisórias. Rodrik (op. cit.), por exemplo, sugere que sejam órgãos público-privados com formato de conselhos de coordenação e deliberação, criados em nível nacional, regional ou setorial. Embora esse autor, de forma coerente com o enfoque de política industrial que adota, proponha que tais conselhos sejam loci de troca de informações e aprendizado social, a complexidade do mundo dinâmico descrito por Dosi (op.cit.) exige que tenham missão mais ambiciosa, funcionando efetivamente como canais de interação das ações público-privadas e de formulação e implementação da estratégia de desenvolvimento focalizada na indústria e centrada na inovação.

\section{Política Industrial e Dinâmica Institucional em Países Selecionados}

Esta seção reúne elementos de políticas industriais contemporâneas de alguns países industrializados ou que fizeram rápido processo de catching up tecnológico. $\mathrm{O}$ propósito é relacionar, em cada caso, os atuais objetivos da política industrial aos elementos institucionais que procuram viabilizar a sua implementação. ${ }^{7}$

Para essa finalidade, algumas experiências relevantes foram escolhidas, sem qualquer outra pretensão que não um exame que permita reflexões e aprendizado. Todos os países possuem tradições e trajetórias históricas diferentes, mas reiterados compromissos de constituição de posições sólidas na economia do futuro, lançando mão, para isso, de intervenções deliberadas.

São eles os Estados Unidos, o Japão, a França e a Coreia do Sul. Se os instrumentos e as instituições são plurais, nem por isso as experiências desses países deixam de apresentar ao menos um elemento comum: o reconhecimento de que o lugar de cada país no futuro depende da construção de trajetórias capazes de promover objetivos para além dos horizontes e capacidades de cada protagonista. Assim sendo,

7 A ênfase, portanto, é no presente. Embora fosse desejável, não há espaço neste artigo para recuperar as experiências históricas de política industrial e tecnológica de cada país. Referências bibliográficas serão indicadas em cada caso. 
um novo protagonismo é colocado em cena - formado pela articulação dos atores, organizados por uma visão comum ou por objetivos compartilhados.

Nos Estados Unidos ${ }^{8}$ a política industrial é ativa e protagonista, em que pesem as visões não intervencionistas tão difundidas, e não acompanha as políticas industriais dos demais países, mas é concebida e implementada para enfrentar problemas e resolver desafios de uma realidade nacional e de uma posição geopolítica muito distinta. A balança comercial dos EUA, apesar de ser sistematicamente deficitária, em volumes crescentes há mais de dois decênios, constitui um não-problema para a política econômica estadunidense. O papel do dólar como moeda internacional e como reserva de valor da maior parte dos países permite que o país não apenas conviva com déficits comerciais, como, ademais, torne todos os países sócios estratégicos desses déficits comerciais - uma situação singular no cenário internacional. Se existe algo que possivelmente traria grandes perturbações às relações econômicas internacionais e acentuaria os seus desequilíbrios seria uma política destinada a reverter esses déficits.

O arcabouço da política industrial dos EUA é bastante diferenciado. Ele afirma a supremacia nacional no cenário internacional e revela-se em diversos objetivos estratégicos, como a segurança nacional e a liderança militar. O termo estratégico contrapõe-se ao exclusivamente econômico e às forças de mercado. E as considerações estratégicas dos EUA são apoiadas em orçamentos extraordinariamente elevados e na busca de soluções diferenciadas para os problemas eleitos como prioritários. O abandono pelos EUA de tantas posições industriais e comerciais sólidas nos campos em que a concorrência internacional se tornou mais acirrada é revelador dessa atitude tanto quanto a concentração dos esforços na corrida rumo às novas fronteiras, com uma mobilização de ativos novos e diferenciados, de natureza científica, tecnológica, passíveis de proteção com propriedade intelectual.

O recurso pelos EUA a instrumentos típicos de política industrial é muito mais seletivo pelo fato de que eles são desnecessários no contexto nacional. Um dos fatores mais importantes do sucesso da política industrial dos EUA é a existência de um mercado de capitais - incluindo capitais de risco - único em termos mundiais. ${ }^{9} \mathrm{Em}$ grande medida, esse fator de sucesso pode ser explicado pela riqueza do seu sistema universitário e de pesquisa ${ }^{10}$, largamente financiado por recursos públicos. E quando se trata de construir avanços científicos e tecnológicos, os EUA são possivelmente o

8 Para uma visão histórica das políticas industriais e tecnológicas dos Estados Unidos, bem como da evolução do seu sistema nacional de inovação, consultar Johnson (1984) e Mowery e Rosenberg (1993).

9 Ver, por exemplo, Zysman (1983).

10 Mowery et al. (2004, cap. 2) mostram que a combinação de ensino e pesquisa nas instituições de ensino superior desde a formação do sistema universitário deu aos Estados Unidos vantagens incontestáveis em ciência e tecnologia. 
único país a contar ao mesmo tempo com um grande número de instituições públicas e empresas privadas, mobilizáveis por uma combinação única de estímulos de mercado e de orientação estratégica, de política pública. Um exemplo importante desse argumento está ligado à atual questão energética, vista sob a ótica dual, das grandes corporações estadunidenses e da segurança nacional dos Estados Unidos. Uma vez que a política de aprovisionamento de recursos energéticos está perdendo a sua capacidade de assegurar a supremacia dos EUA e que os seus custos estão crescendo de forma insustentável no longo prazo (inclusive pela rivalidade com a China), a busca de soluções energéticas de fontes renováveis vem conquistando importância na definição das suas políticas. Um dos campos em que elas têm sido mais ativas no período recente é precisamente nos combustíveis líquidos que possam substituir a gasolina. O programa estadunidense neste campo desdobra-se em pelo menos três eixos complementares, reveladores do alcance de seus objetivos. $\mathrm{O}$ primeiro eixo refere-se a um notável subsídio aos combustíveis líquidos (etanol) originários do milho. ${ }^{11} \mathrm{O}$ segundo vincula-se à gradual introdução desses combustíveis na matriz de transporte. ${ }^{12} \mathrm{O}$ terceiro eixo está relacionado com o avanço decidido dos EUA em direção à fronteira tecnológica neste campo, das energias renováveis. ${ }^{13} \mathrm{O}$ programa de pesquisa dos EUA neste tema é impressionantemente vasto e combina uma enorme gama de interesses, instituições e instrumentos, sob um lema assim resumido: não existem restrições econômicas às pesquisas sobre energias renováveis. Nenhum outro país poderá reproduzir tal ambição.

O sucesso japonês está fortemente vinculado às suas políticas industriais, desde sempre muito ativas e eficazes. ${ }^{14}$ Depois da crise recente (anos 1990), o Japão relançou-se numa política industrial, com novos desafios e uma nova institucionalidade. A base da nova política industrial japonesa foi estabelecida pelo Relatório Nakagawa, lançado em maio de 2004 e (sub)intitulado "para uma estrutura industrial sustentável e competitiva" (METI, 2004). Nele se reconhece a nova concorrência asiática e a necessidade de enfrentar alguns novos desafios - entre eles o envelhecimento da população japonesa. Depois de um longo período de crise macroeconômica, durante o qual a política econômica se debateu com questões relacionadas à insuficiência

11 O governo dos EUA gastou, nos 10 anos entre 1995 e 2004, uma média anual de 4,2 bilhões de dólares com subsídios ao milho. Ver "Mountains of corn and a sea of farm subsidies", New York Times, 9/11/2005.

12 "Declaring a new direction in energy policy, the U.S. House of Representatives on Saturday passed the Energy Bill titled 'The New Direction for Energy Independence, National Security, and Consumer Protection Act'. In it, the American legislators approve US\$16 billion in taxes on oil companies, while providing billions of dollars in tax breaks and incentives for renewable energy, biofuels and conservation efforts." U.S. House passes energy bill: boost to biofuels, CCS and renewables. Biopact, 06/8/2007.

13 O Laboratório Nacional de Energias Renováveis pode ser considerado o principal centro de pesquisas público nessa área, mas as verbas do Departamento de Energia e das empresas privadas irrigam inúmeras instituições. Empresas privadas respondem a esse sinal forte da política industrial estadunidense: a British Petroleum custeou um laboratório (Lawrence Berkeley National Laboratory) na Universidade da Califórnia dedicado a esse tema.

14 Ver os já citados trabalhos de Johnson (1982) e Odagiri e Goto (1993). 
de demanda e ao excesso de capacidade produtiva, a política econômica pretendeu relançar objetivos mais positivos e afirmativos - entre eles a retomada dos investimentos e o estabelecimento de novas competências. Entre os objetivos da nova política industrial japonesa estão "o estabelecimento de tecnologias e indústrias que assegurem ao Japão uma posição de liderança nos mercados mundiais durante os próximos 20-30 anos". Para alcançar esse objetivo, a política industrial deverá "coordenar tecnologias de ponta (por exemplo, nanotecnologia, tecnologia de informação e biotecnologia) com tecnologias, técnicas e habilidades artesanais tradicionais do Japão". Na sua missão, a nova política industrial japonesa vê-se como market-frien$d l y$, tendo como base o estabelecimento de uma "visão compartilhada do futuro", com "integração das medidas e dos objetivos", uma integração que deveria envolver, segundo o relatório Nakagawa, os stakeholders principais, incluindo os empresários, o governo, as instituições educacionais e as comunidades locais. O relatório enfatiza a necessidade de articulação e coordenação em todos os níveis - entre o público e o privado, entre os diferentes entes públicos, entre as empresas de uma mesma cadeia e entre empresas de diferentes cadeias. No bojo dessa articulação está o Ministério da Economia, do Comércio e da Indústria (METI, em inglês) ${ }^{15}$, numa nova configuração que evidentemente vai muito além da antiga fórmula do MITI (Ministry of International Trade and Industry), relacionando principalmente indústria e comércio exterior.

A nova política industrial francesa, "relançada" a partir de $2005^{16}$, está focalizada na inovação nos setores de "alta tecnologia", e não sobre o conjunto de atividades industriais ou econômicas. A política industrial francesa explicita a necessidade de articulação entre atores distintos e foi lançada a partir de uma encomenda direcionada pelo presidente da França a um grande empresário, dirigente de uma das maiores e mais antigas empresas francesas. A hipótese é de que as inovações serão cada vez mais criações coletivas, combinando conhecimentos e competências dificilmente encontráveis numa única empresa ou instituição. A inovação, nesta visão, é considerada um processo de reunião de especializações de diferentes campos, muito mais do que especializações acentuadas em um único campo. Disso decorre a busca de novos mecanismos de coordenação para propiciar maiores possibilidades de parceria e novas parcerias. Os documentos franceses falam em hibridação entre

$15 \mathrm{Na}$ estruturação dos horizontes de futuro da estrutura industrial japonesa, a política industrial definiu sete grandes apostas e quatro "clusters" destinados à revitalização das economias regionais do Japão. As apostas estão representadas por quatro produtos ou grupos de produtos - células de combustível, eletrônicos de consumo digitais, robôs e produção de conteúdo - ao lado de três áreas de caráter mais amplo e genérico - produtos e serviços de saúde e cuidados pessoais, produtos e serviços para o ambiente e a energia e serviços de apoio aos negócios. As ações destinadas à revitalização regional desdobram-se em quatro dimensões principais: indústrias avançadas, novos negócios na indústria (manufatureira), inovação nas indústrias de serviços (regionais) e agregação de valor à indústria de alimentos. Ver o Relatório Nakagawa (METI, op. cit.).

16 Beffa (2005). Para um histórico da política industrial e da construção do sistema nacional de inovação francês, ver Chesnais (1993). 
diferentes trajetórias e campos do conhecimento. Estas parcerias e as confluências de trajetórias envolvem tanto os pesquisadores e as empresas quanto tipos e agrupamentos de empresas.

Existe uma dimensão mais relevante em que estas configurações são pensadas e buscadas: a dimensão regional. A PI francesa busca de forma explícita uma emulação das experiências da Califórnia e de Bangalore, onde as complementaridades estão associadas a efeitos de rede e a externalidades positivas, mas acrescentando um elemento tipicamente francês: a organização do território ${ }^{17}$, vinculado ao desenvolvimento local.

Esta visão do processo de inovação conduziu a uma correspondente reorganização institucional, pelo agrupamento das estruturas, dos instrumentos e das competências de diversos organismos de apoio às médias e pequenas empresas, especialmente em termos de apoio à inovação, financiamento e informações. ${ }^{18} \mathrm{~A}$ nova política industrial francesa promoveu, também, a criação da Agência Nacional de Pesquisa em fevereiro de 2005, com o objetivo de apoiar as "pesquisas fundamentais e aplicadas" e de contribuir para a transferência dos resultados da pesquisa pública para as empresas. Por último, a PI francesa promoveu a criação da Agência para a Inovação Industrial (AII), em agosto de 2005. O diagnóstico desta agência e as linhas de sua ação estão associados à ideia de ser a estrutura industrial francesa excessivamente composta de setores de baixa intensidade tecnológica, uma conclusão que esteve em discussão e foi incorporada no Relatório Beffa. ${ }^{19}$ Em conformidade com esta conclusão, o esforço da AII deveria estar direcionado para as altas tecnologias e para programas mobilizadores comandados pelas grandes empresas em articulação com empresas pequenas e médias e com laboratórios de pesquisa. Os exemplos mencionados desses programas mobilizadores seriam: o veículo limpo, o novo trem de alta velocidade ou as novas telecomunicações. Evidentemente, a despeito de várias outras rupturas com o passado, a política industrial francesa ainda permanece vinculada à ideia dos grandes programas; mas uma diferença importante com relação ao passado parece residir no fato de que as grandes apostas deixaram de justificar-se no quadro do mercado nacional francês, para se tornarem justificáveis apenas numa dimensão europeia ou global.

17 A França possui um termo e um ministério característico: aménagement du térritoire. Literalmente, a organização do território.

18 O documento (BEFFA, op. cit.) fala em "regroupement des différents instruments de soutien aux PME dans la société anonyme Oséo-Anvar; le groupe Oséo-Anvar a été créé en 2005 en réunissant les compétences de la BDPME, de l'Anvar et du GIE Agence des PME pour agir comme soutien à l'innovation, financement et information des PME".

19 Beffa (op. cit.). O relatório Beffa foi assim designado a partir do nome do seu relator, Jean-Louis Beffa, presidente da Saint-Gobain (uma das maiores empresas multinacionais de origem francesa). 
A atual política industrial da Coreia do Sul pode ser considerada o caso por excelência de uma formulação explícita de construção de um sistema nacional de inovação voltado para o século 21, quer dizer, para assegurar à Coreia um lugar de proeminência no sistema internacional com base na ciência, na tecnologia, no conhecimento e na inovação. ${ }^{20}$ A estruturação do sistema nacional de inovação coreano possui elementos institucionais destacadamente importantes, entre eles a promoção do ministro da Ciência e da Tecnologia a um escalão hierárquico superior (de ministro a vice-primeiro-ministro), funcionando como vice-presidente do Conselho Nacional de Ciência e Tecnologia, presidido pelo presidente da República.

Para o estabelecimento do seu novo sistema nacional de inovação, a Coreia focalizou cinco áreas principais: (1) o fortalecimento das capacidades inovativas dos atores da inovação, a saber: as empresas e as universidades e os institutos de pesquisa; (2) a produção e a industrialização de resultados singulares de pesquisa e desenvolvimento, uma ação resumida na expressão "inovação de desempenho e difusão"; (3) a inovação de caráter sistêmico, desdobrada em duas ações principais: o fortalecimento da colaboração entre entidades líderes e o processo de globalização; e a coordenação de políticas, orçamentos e programas de forma eficiente e efetiva; (4) assegurar investimentos eficientes e promover a qualidade da mão de obra; e (5) criar "ecossistemas comandados pela inovação, incluindo a cultura da inovação".

Estes objetivos, que em vários casos parecerão genéricos, desdobram-se em objetivos e ações muito mais específicos e bem determinados. Assim, por exemplo, existe na nova política uma menção explícita à necessidade de prospectivas tecnológicas (foresight) e de sua integração com os programas de P\&D. Mas as ações da política industrial e de inovação coreana deslocam-se para um patamar superior quando estabelecem metas específicas como o aumento do emprego nas áreas de C\&T, de 16\% em 2002 para mais de 25\% em 2012, com o propósito de tornar a Coreia uma das oito potências tecnológicas mundiais. Metas mais específicas, tão mobilizadoras quanto ambiciosas, também foram estabelecidas. É este o caso da meta voltada para a conquista da posição de liderança mundial em 200 produtos.

Os elementos apresentados nesta seção permitem constatar que os países com pretensões na cena econômica do futuro adotam, invariavelmente, políticas para estruturarem as suas trajetórias em direção a essa condição. Nenhum, nem mesmo

20 A promoção do conhecimento a elemento central da política industrial da República da Coreia começou logo após a crise do México, em 1997, que em parte motivou várias iniciativas privadas direcionadas para escapar de possíveis armadilhas semelhantes. Elas culminaram com uma ação governamental em 2000, quando o Ministério das Finanças encomendou ao Banco Mundial um relatório sobre o tema: Transition to a Knowledge-Based Economy (Junho de 2000). Este Relatório consubstanciou, com abrangência e consistência, uma nova fase da Política Industrial coreana. Ver Andersson e Dahlman (2001). Para um histórico da política industrial e tecnológica da Coreia, ver Chang (1994, cap. 4), além dos já citados trabalhos de Kim (1993 e 2005). 
aqueles que possuem posições destacadas contemporaneamente, dão por assegurada a posição. Da mesma forma, nenhum, nem mesmo os Estados Unidos, confia de forma exclusiva nos mecanismos exclusivos do mercado para trilhar esse caminho entre o presente e o futuro. Estados Unidos, Japão, França e Coreia do Sul, como outros países, pretendem, cada um a seu modo, conquistar uma posição na economia do futuro e todos eles a veem a partir de uma visão global, de uma economia globalizada, integrada, onde evidentemente a China - e a produção massificada, de baixos custos - ocupa um papel proeminente. $\mathrm{O}$ caminho em direção às novas tecnologias, à integração ágil e consistente da ciência e do conhecimento, está presente em todas as formulações. Estão presentes também escolhas, presididas pela identificação das competências existentes e passíveis de construção, de um lado, e os desenhos de futuro, de outro lado.

A política industrial, de tecnologia e de inovação lida com essa realidade incontornável: fazer escolhas. Mas ela sabe que essas escolhas não podem ser arbitrárias ou casuísticas, e por isso destaca os papéis de orientação, coordenação e articulação. Quando necessário, os arranjos institucionais são refeitos e voltam-se para os propósitos específicos. O ministério japonês da economia integra-se ao do comércio e da indústria, os organismos franceses articulam-se para as pequenas e médias empresas, o ministério coreano encarregado da ciência e da tecnologia vê-se alçado a uma nova posição - os desenhos institucionais acomodam-se aos propósitos da política industrial.

\section{Instituições e Políticas Industriais no Brasil: Problemas de Implementação}

Até fins da década de 1970 o desenvolvimento industrial do Brasil foi fortemente estimulado por políticas industriais. Essas políticas destacaram-se tanto por aspectos meritórios, criando uma estrutura industrial integrada e diversificada, quanto por problemas relacionados a protecionismo excessivo e indiscriminado, sem metas e prazos; subsídios de várias naturezas, e desatenção ao desenvolvimento tecnológico e à exportação. É inegável, no entanto, que aquelas políticas foram efetivamente implementadas por uma organização institucional do Estado que havia sido construída ao longo de todo o período a partir da década de 1930.

De 1980 em diante, o País praticamente deixou de implementar políticas industriais, apesar de várias iniciativas do governo para definir tais políticas, algumas vezes chegando a lançar documentos oficiais que, no entanto, pouco ou nada concretizaram. Entre essas iniciativas, cumpre mencionar: a política industrial elaborada pela Comissão para o Plano de Ação do Governo (1984), que feneceu com a morte do presidente eleito Tancredo Neves; o documento de política industrial elaborado 
por comissão criada no Ministério do Planejamento em 1986, que foi descartado por contrariar o congelamento de preços do Plano Cruzado; a Nova Política Industrial, instituída em 1988, da qual pouco resultou concretamente, cabendo mencionar apenas um instrumento específico que perdurou - o PDTI (Programa de Desenvolvimento Tecnológico Industrial); a PICE - Política Industrial e de Comércio Exterior, de 1991, que não sobreviveu às crises política e econômica do governo Collor; a proposta de política industrial elaborada por comissão criada pelo governo em 1995, no início do primeiro mandato do governo Fernando Henrique Cardoso, que nem chegou a ser formalizada, e a PITCE - Política Industrial, Tecnológica e de Comércio Exterior do Governo Lula, anunciada em 2003, mas pouco implementada desde então, e o que é pior, cuja existência por vezes nem é lembrada pelos responsáveis por algumas das principais instituições da área. ${ }^{21}$

Apesar disso tudo, algumas políticas setoriais chegaram a ser implementadas, como as de informática e do regime automotivo, este no âmbito e por imperativos do Mercosul, assim como foram implementados programas de amparo a indústrias tradicionais por meio de medidas de salvaguardas e antidumping, no âmbito dos acordos da OMC. Isto, porém, não deve ser visto como atenuante; ao contrário, fazer políticas setoriais sem uma política industrial de referência pode levar a resultados ineficientes, transitórios e de elevado custo social.

É evidente que parte dos insucessos se deve à instabilidade macroeconômica típica do período pós-1980, mas tem a ver também com o que poderíamos chamar de "destruição não criadora” de instituições. Desde 1980 até o final dos anos 1990 muitas das principais instituições de política industrial e de ciência e tecnologia sofreram um contínuo processo de esvaziamento, com perda de recursos e de pessoal técnico e desvirtuamento de funções. Posteriormente, as condições operacionais dessa organização institucional foram parcialmente restauradas, mas muitas instituições ainda lutam com problemas de várias ordens e, sobretudo, não têm evoluído no que diz respeito a capacitar-se; para implementar uma política industrial e tecnológica contemporânea, com pretensões em relação à posição nacional na economia do futuro.

O restante desta seção discute resumidamente alguns dos problemas que afetam a capacidade de implementação da política industrial e tecnológica no País, com foco nas instituições governamentais que constituem o eixo central de formulação e implementação dessa política. Embora se saiba que, num sistema institucional que dá suporte a atividades tecnológicas e de inovação das empresas há também

21 Para um histórico da política industrial e tecnológica até meados dos anos 1990, ver, entre outros, Suzigan e Villela (1997). Documentos oficiais referentes aos anos mais recentes podem ser encontrados na internet, nos sítios correspondentes aos ministérios do Desenvolvimento, Indústria e Comércio (MDIC) e da Ciência e Tecnologia (MCT). 
instituições não-mercado, ${ }^{22}$ tais instituições não serão discutidas neste artigo, cujo foco é o núcleo da organização institucional do Estado na área.

Desde logo é necessário esclarecer que o ponto de vista aqui exposto é fortemente crítico, mas o leitor deve entender essa crítica como um passo essencial para construir um sistema institucional que seja capaz de responder às necessidades da dinâmica da indústria e da tecnologia. Esse ponto de vista é o de que as atuais instituições da área não atuam de forma sistêmica ou articulada, com base em visão compartilhada; estão, em muitos casos, envelhecidas, marcadas por suas missões do passado - por isso, têm dificuldades para responder aos desafios impostos seja pela dinâmica do crescimento econômico impulsionado por inovações, seja por uma visão de futuro da indústria e da tecnologia; constituem um conjunto extremamente complexo, fragmentado, com grande dispersão de instrumentos que, por vezes, geram conflitos de competências; operam com quadros técnicos que ainda não têm todas as capacitações requeridas por missões mais qualitativas e sofisticadas, relacionadas a visões prospectivas de política industrial e tecnológica; geram grandes dificuldades em termos de articulação de instrumentos e da política industrial com outras políticas e com o setor privado, e, sobretudo, têm um frágil comando político e uma séria deficiência de coordenação.

Visando substanciar esse ponto de vista, apresenta-se inicialmente o conjunto das principais instituições da área de política industrial e tecnológica, suas funções e respectivos instrumentos e, em seguida, faz-se uma avaliação sucinta dos principais problemas, na mesma ordem em que foram mencionados acima.

\subsection{Principais Instituições de Política Industrial no Brasil}

A construção institucional visando ao desenvolvimento industrial e tecnológico do País começou há mais de meio século. O fato de algumas das instituições atuais da área serem antigas não é, em si, um mal. Instituições sólidas podem e devem ser duradouras, mas precisam evoluir, mudar, adaptar-se às mudanças econômicas, tecnológicas, estruturais, organizacionais e sociais. Do contrário, passam a dificultar o desenvolvimento econômico, o progresso técnico e a melhoria do bem-estar social.

Os problemas das instituições de política industrial e tecnológica do Brasil decorrem justamente do fato de não terem evoluído suficientemente e de forma coerente com a evolução da indústria, da ciência e da tecnologia. O eixo central da organização institucional da área, com poucas exceções, é o mesmo das décadas de 1950-70,

22 Como, por exemplo, universidades e institutos de pesquisas que interagem com empresas, além de instituições de esferas regionais, setoriais e outras. 
quando os objetivos eram mais simples: promover o desenvolvimento de setores específicos. Hoje os objetivos são muito mais qualitativos e refinados: não se trata de construir setores, e sim de movê-los em direções determinadas, criar condições contextuais para que possam capacitar-se a inovar e ganhar produtividade e eficiência produtiva e, com isso, desenvolver-se de forma sustentada. E, em alguns casos, as instituições continuam estrutural e operacionalmente presas às práticas (ou tecnologias sociais) antigas. Esse eixo central de formulação e implementação da política industrial e tecnológica compõe-se principalmente das instituições que constam do Quadro 1 a seguir.

Cada instituição dispõe de órgãos, departamentos e programas específicos responsáveis pela execução de políticas e pela administração dos respectivos instrumentos de implementação. Para os propósitos deste trabalho, é dispensável detalhar os organogramas das instituições e respectivos programas, bastando delinear as características gerais, em termos de funções e principais instrumentos, das instituições que compõem o núcleo institucional responsável pela política industrial e tecnológica.

Em seguida, apresenta-se uma avaliação resumida sobre a atuação dessas instituições procurando ver até que ponto essa atuação pode ser considerada adequada tendo em vista a implementação de uma política industrial e tecnológica capaz de dar novo dinamismo à indústria e levá-la a uma posição de destaque no cenário da economia mundial. Esse resumo enfatiza os pontos de vista críticos anteriormente mencionados de que as instituições: (1) não atuam de forma sistêmica, (2) estão em grande parte envelhecidas, (3) constituem um conjunto extremamente complexo, (4) operam com quadros técnicos que ainda não reúnem todas as capacitações requeridas por missões mais qualitativas e sofisticadas de política industrial e tecnológica, (5) geram grandes dificuldades em termos de articulação, e (6) têm frágil comando político e problemas de coordenação. 


\begin{tabular}{|c|l|}
\hline Instituições* & \multicolumn{1}{|c|}{ Formas de Atuação e Principais Instrumentos } \\
\hline CNDI & $\begin{array}{l}\text { Instância superior, órgão consultivo para as diretrizes do desenvolvimento } \\
\text { industrial do País, vinculado à Presidência da República, composto por 13 } \\
\text { ministros e pelo presidente do BNDES. }\end{array}$ \\
\hline MDIC & Formulação da política; defesa comercial. \\
\hline \multicolumn{1}{|c|}{ - BNDES } & Financiamento para investimento, exportação. \\
\hline - INPI & Propriedade industrial, transferência de tecnologia, marcas e patentes. \\
\hline - INMETRO & $\begin{array}{l}\text { Normas técnicas e legais, metrologia, qualidade, certificações, acreditação de } \\
\text { laboratórios. }\end{array}$ \\
\hline - APEX & Promoção de exportações, internacionalização de empresas. \\
\hline MCT & $\begin{array}{l}\text { Política científica e tecnológica; fomento a pesquisa, formação de Recursos } \\
\text { Humanos. }\end{array}$ \\
\hline - FINEP & Financiamento a inovação e pesquisa Científica \&Tecnológica \\
\hline - CNPq & $\begin{array}{l}\text { Fomento a pesquisa Científica \&Tecnológica, desenvolvimento tecnológico, } \\
\text { formação de Recursos Humanos. }\end{array}$ \\
\hline - FNDCT/Fundos Setoriais & Fomento a atividades de P\&D, Ações Transversais. \\
\hline MF & Incentivos de renúncia fiscal, tarifa aduaneira, ex-tarifários. \\
\hline ME/CAPES & Formação RH, fomento pós-graduação, acesso à produção científica. \\
\hline MJ/SDE-CADE & Defesa da concorrência. \\
\hline MRE & $\begin{array}{l}\text { Promoção comercial, normas e regulamentos de acordos multilaterais de } \\
\text { comércio (OMC), acordos regionais de comércio e de integração econômica. }\end{array}$ \\
\hline SEBRAE & Apoio ao desenvolvimento de Micro/Pequenas Empresas, desenvolvimento local. \\
\hline
\end{tabular}

\section{Quadro 1 - Instituições de Política Industrial e Tecnológica do Brasil}

* Acrônimos: APEX - Agência de Promoção de Exportações; BNDES - Banco Nacional de Desenvolvimento Econômico e Social; CADE - Conselho Administrativo de Defesa Econômica; CAPES - Coordenação de Aperfeiçoamento de Pessoal de Nível Superior; CNDI - Conselho Nacional de Desenvolvimento Industrial; CNPq - Conselho Nacional de Pesquisa; CPqD - Fundação Centro de Pesquisa e Desenvolvimento em Telecomunicações; EMBRAPA - Empresa Brasileira de Pesquisa Agropecuária; FINEP - Financiadora de Estudos e Projetos; FNDCT - Fundo Nacional de Desenvolvimento Científico e Tecnológico; INMETRO - Instituto Nacional de Metrologia; INPE - Instituto de Pesquisas Espaciais; INPI - Instituto Nacional da Propriedade Industrial; MCT Ministério de Ciência e Tecnologia; MDIC - Ministério do Desenvolvimento, Indústria e Comércio Exterior; ME - Ministério da Educação; MF - Ministério da Fazenda; MJ - Ministério da Justiça; MRE - Ministério das Relações Exteriores; SDE - Secretaria de Defesa Econômica; SEBRAE Serviço Brasileiro de Apoio à Pequena Empresa. Observação: Não estão incluídas as instituições regionais e setoriais, nem as instituições de esferas de governo que não o governo federal.

Fonte: elaboração própria. 


\subsection{Avaliação ${ }^{23}$ da Atuação das Instituições - um Resumo com Ênfase nos Principais Problemas}

A avaliação feita a seguir é bastante sumária e tem o objetivo específico de destacar os problemas que dificultam a implementação da política industrial e tecnológica. Não entra em detalhes sobre cada instituição, seus modos de operação, seus programas, sua organização interna, sua burocracia, o que seria tarefa para um trabalho de mais fôlego, especificamente dedicado à reforma das instituições. O que se espera é que os rumos dessa reforma - caso venha a ser feita - possam ser norteados pela discussão aqui empreendida.

O primeiro problema a ser apontado é o da ausência de atuação sistêmica do conjunto de instituições. Por que deveria funcionar como um sistema? Porque seria inconcebível, e muito provavelmente impossível, implementar uma estratégia de desenvolvimento industrial fundada em inovação sem que o conjunto de instituições envolvidas estivesse operando em sincronia, articuladamente e com o mesmo foco. É essa a essência de um sistema nacional (ou setorial) de inovação. É isso que garante que, por exemplo, se o objetivo for o desenvolvimento de uma nova geração de equipamentos para hidrólise, visando a uma inovação na produção de etanol, haja financiamento compatível, apoio para $\mathrm{P} \& \mathrm{D}$ in house, canais de articulação com o setor privado, interação com universidades e institutos de pesquisa, e assim por diante. Garante também melhores possibilidades de articulação com outras políticas públicas como, por exemplo, as de agroindústria, infraestrutura, ciência e tecnologia, educação.

Nas últimas duas ou três décadas isto não tem acontecido no País - e talvez se possa dizer que nunca aconteceu, com a possível exceção (parcial) dos períodos históricos de implementação do Plano de Metas, na década de 1950, e do II Plano Nacional de Desenvolvimento, nos anos 1970. Mais recentemente, apesar de várias inovações institucionais e do foco criado pela PITCE - Política Industrial, Tecnológica e de Comércio Exterior, o que se verifica é que as instituições da área tendem a atuar de forma autônoma, assincrônica (mesmo quando em sintonia com as prioridades da PITCE), com frequentes conflitos de competências, sobreposição de funções, duplicação de esforços, e o que é pior: deixam de atender integralmente as ações

23 Essa avaliação baseia-se nos resultados de uma série de reuniões, debates e seminários realizados no âmbito de um projeto de pesquisa promovido e coordenado pela CNI - Confederação Nacional da Indústria em 2007. Esse projeto, que contou com participantes de várias instituições e profissionais acadêmicos, gerou um conjunto de estudos apresentados no II Congresso Brasileiro de Inovação na Indústria, São Paulo, 23-25 de abril de 2007, sob os auspícios da CNI. Complementarmente, foram realizadas reuniões e entrevistas com profissionais que trabalham na área, inclusive nas instituições mencionadas. Apesar de óbvia, cabe a ressalva de que os pontos de vista aqui expostos são de exclusiva responsabilidade dos autores. 
institucionais requeridas pela implementação de uma estratégia como a preconizada pela PITCE.

O segundo problema mencionado é o que se denominou "envelhecimento das instituições", não no sentido literal do termo, mas sim significando que, nos termos da análise de Nelson (2006), elas se tornaram enrijecidas, presas a tecnologias sociais há muito estabelecidas, bem como a formas de atuação típicas de seu passado histórico e do papel que desempenharam nesse passado, em que a política industrial tinha objetivos mais singelos, ou seja, desenvolver setores ou indústrias específicas e construir uma estrutura industrial. $\mathrm{O}$ ambiente institucional geral mudou significativamente - com a abertura da economia, as privatizações, as agências reguladoras, as novas normas internacionais de comércio, direitos de propriedade intelectual mas as instituições estrito senso pouco mudaram.

De forma semelhante à análise de Nelson (ibidem), mas trabalhando com um enfoque teórico distinto, Bueno (1996) considera que a dinâmica institucional deve interagir com a dinâmica econômica. Ressalta, entretanto, que a dinâmica institucional "está sujeita a histerese", que ocorre "quando as decisões tomadas em cada etapa da história de um sistema conformam o conjunto de ações factíveis para o sistema nos momentos seguintes" (p. 335). Idealmente, a dinâmica econômica e a dinâmica institucional devem andar pari passu, ou a dinâmica econômica - leia-se a política industrial e tecnológica - deve ser capaz de induzir mudanças na estrutura institucional. Mas, no Brasil, nem a PITCE nem suas antecessoras tiveram esse poder. O que acontece é que, nas palavras de Bueno, algumas instituições são capazes

de induzir determinadas políticas (...) que restringem o país a trajetórias menos eficientes de crescimento econômico; elas, em outras palavras, limitam a eventual potência de medidas que poderiam induzir mudanças institucionais, exclusivamente pelo seu poder de proteger os interesses nelas constituídos, resistindo a essas mudanças. (ibidem, p. 345).

Na mesma linha, Nelson (2006, p. 37) reconhece que tecnologias sociais e instituições estabelecidas "podem ser difíceis de desalojar".

Apesar da provável resistência a mudanças, a reforma do sistema institucional de política industrial parece incontornável. O desenho atual, mesmo com algumas inovações introduzidas recentemente, é retrato tanto do envelhecimento quanto da recorrente criação ad hoc de instrumentos e/ou instâncias superiores do Estado para tentar planejar, coordenar, articular os vários segmentos e implementar a política. Tem sido prática comum criar novas instituições sempre que há percepção da 
necessidade de coordenar, ou quando um novo programa ou um novo instrumento é criado, ou ainda quando muda a administração federal. Essa prática acaba agravando o problema ao tornar cada vez mais complexa a organização institucional do Estado.

O ideal seria uma organização institucional que fosse, sobretudo, funcional do ponto de vista da implementação das políticas. Grande parte dos conflitos de competência, da superposição de funções ou da ineficiência deriva da ausência de uma visão comum, compartilhada, quanto aos objetivos, às metas e ao escopo da política industrial. Em outras palavras, a organização do Estado e seus mecanismos de articulação e de mobilização, os instrumentos e os meios, devem ser moldados em função das políticas que se pretende implementar e dos resultados que se deseja alcançar, com base em metas, cronogramas, definição de responsabilidades, e mecanismos de acompanhamento e cobrança.

No entanto, a tarefa de reforma do sistema institucional, de modo a torná-lo adequado a uma estratégia de desenvolvimento industrial impulsionada por inovação, é complexa, tanto em termos técnicos quanto políticos. Mas é reconhecidamente um dos problemas mais urgentes e mais difíceis de serem enfrentados no futuro próximo.

O terceiro problema é o da complexidade do atual conjunto de instituições. O sistema institucional mais amplo - órgãos, marco regulatório e instrumentos da política industrial e tecnológica brasileira é, de fato, extremamente complexo. Historicamente, desde a década de 1930, criaram-se instituições, programas específicos, normas legais e instrumentos, e nos anos recentes vários outros foram adicionados, sem que houvesse uma consolidação que simplificasse o sistema. $\mathrm{O}$ resultado desse processo histórico é um número excessivo de órgãos, alguns com precária capacidade de mobilizar recursos, administrando uma variedade de instrumentos dispersos e desarticulados, muitas vezes com sobreposição de funções e regras que se superpõem, dificultando uma ação efetiva, articulada e coordenada do governo. Essas várias gerações de instituições e instrumentos, criados para responder a desafios e a contextos históricos específicos, não necessariamente são capazes de responder aos desafios que teriam de ser enfrentados para implementar uma estratégia de crescimento baseada em inovação.

Algumas das instituições mais relevantes foram criadas no pós-guerra, como por exemplo, o CNPq (1951) e o BNDE (1952), depois transformado em BNDES ao incorporar o objetivo de desenvolvimento social. O próprio BNDE acabaria por dar origem à FINEP (1967) e em seguida seria criado o FNDCT (1969). Outra parte desse arcabouço institucional é herança dos anos do chamado "milagre econômico", 
entre fins da década de 1960 e início dos anos 1970, no contexto de uma economia fechada e com forte presença do Estado, quando inúmeros organismos foram criados, entre os quais: INPI, INPE, SEBRAE, INMETRO, EMBRAPA, CPqD. Na década de 1980 pouco se acrescentou, sendo a grande novidade a criação do Ministério de Ciência e Tecnologia, "fato que respondia muito mais às demandas políticas da comunidade acadêmica, no contexto da redemocratização do país, do que propriamente a uma estratégia de desenvolvimento" científico e tecnológico. ${ }^{24}$ E desde então as demandas acadêmicas têm-se acentuado, como por exemplo, no caso da criação dos Fundos Setoriais, cujos recursos são das empresas, mas têm de ser gastos nas instituições de ciência e tecnologia. ${ }^{25}$

A partir de meados dos anos 1990, esse sistema foi ampliado e atualizado para atender às exigências decorrentes de mudanças estruturais impostas pelas privatizações, pelo novo papel do Estado consubstanciado na criação das agências reguladoras, pela nova política de defesa da concorrência. Essas mudanças alteraram profundamente a natureza da organização institucional do Estado. Da mesma forma, a liberalização comercial e a adesão aos acordos do Mercosul e da OMC também implicaram mudanças importantes em várias áreas das políticas de comércio exterior que afetam a política industrial, como: a tarifa consolidada nos acordos da OMC; a tarifa externa comum do Mercosul; a nova legislação de defesa comercial; as regras antidumping, de salvaguardas e medidas compensatórias; a nova legislação de direitos de propriedade intelectual (TRIPS). Além disso, foi reestruturada a política de promoção comercial, com a criação da APEX e um papel mais ativo do MRE. Por fim, aprovou-se um conjunto novo de instrumentos legais, em que se destacam a Lei de Cultivares, a Lei do Software, as Leis de Biossegurança, a Lei de Inovação e novos regimes fiscais de incentivos, como a Lei do Bem e o Estatuto da Micro e da Pequena Empresa, além de um novo regime fiscal, consolidado na Lei de Responsabilidade Fiscal, que coloca novos parâmetros para a ação pública em temas como incentivos e subvenções, e, mais recentemente, no início de 2007, a Política Nacional de Biotecnologia e os novos programas e incentivos setoriais do PAC - Programa de Aceleração do Crescimento.

A este já complexo quadro institucional somam-se os órgãos tradicionais de ação governamental na área de política industrial, como o MDIC, o BNDES, a FINEP, além, é claro, do próprio Ministério da Fazenda, instância decisiva na área eco-

24 Ponto de vista defendido por C. A. Pacheco em documento não publicado, intitulado "Política Industrial: Uma Agenda de Reformas Institucionais" (s. d.). Esse documento foi utilizado neste artigo com autorização do autor, a quem agradecemos.

25 Esses recursos, na verdade, têm sido retidos pelo Tesouro Nacional para cumprir um dos objetivos prioritários da política econômica - a geração de superávits primários, e só recentemente foi iniciado um cronograma de liberação até 2010. 
nômica, do Ministério de Ciência e Tecnologia, do Ministério do Planejamento e Orçamento, e de órgãos setoriais e regionais.

A dificuldade de articular e coordenar esse enorme aparato institucional levou o Executivo a criar a CAMEX, ${ }^{26}$ enfatizando seu papel coordenador, e a instituir as Câmaras de Políticas de Desenvolvimento Econômico e de Política Econômica, no âmbito da Casa Civil da Presidência da República. Em paralelo, seguindo o exemplo da criação do CGEE - Centro de Gestão e Estudos Estratégicos do MCT em 2001, foram criados pelo mesmo instrumento legal em fins de 2004, e regulamentados em princípios de 2005, o CNDI - Conselho Nacional de Desenvolvimento Industrial e a ABDI - Agência Brasileira de Desenvolvimento Industrial, no contexto da PITCE, instituída em fins de 2003. A ABDI, instituída como pessoa jurídica de direito privado sem fins lucrativos, de interesse coletivo e de utilidade pública, seria a coordenadora, articuladora e executora da PITCE, atuando em consonância com as diretrizes e estratégias definidas pela Câmara de Desenvolvimento Econômico, pela Câmara de Política Econômica, pelo CNDI, e por seu próprio Conselho Deliberativo, instâncias essas que incluem membros do governo e da sociedade civil.

Além da questão institucional envolvida, uma vez que uma agência de natureza privada, embora de interesse público, não tem mandato para coordenar órgãos do governo nem para executar políticas públicas, há que se considerar a extrema complexidade do processo de formulação e implementação da política, decorrente não só do grande número de instituições envolvidas como também das várias instâncias decisórias. Esses são dois aspectos de um mesmo problema - o da complexidade do conjunto das instituições - que dificulta a implementação da política industrial e tecnológica no país.

O quarto problema mencionado é o da necessidade de adequar a capacitação dos quadros técnicos das instituições da área aos novos requisitos da política industrial e tecnológica. Uma avaliação mais abrangente e acurada das capacitações existentes depende de trabalho especificamente dedicado a isso. Porém, com base em informações de domínio público e em contatos com técnicos e dirigentes de algumas das instituições, é possível afirmar que, comparativamente às instituições das áreas mais prioritárias de política econômica, tais como o Banco Central, o Ministério da Fazenda e a Receita Federal do Brasil, os quadros técnicos das instituições da área - com notáveis exceções - têm níveis de formação e de treinamento inferiores, e não reúnem as capacitações mais avançadas que seriam necessárias para imple-

26 A CAMEX - Câmara de Comércio Exterior, órgão integrante do Conselho de Governo, foi regulamentada em junho de 2003 e responde pela formulação, adoção, implementação e coordenação de políticas de comércio exterior. É presidida pelo ministro do MDIC e integrada pelos ministros da Casa Civil, Relações Exteriores, Fazenda, Agricultura e Planejamento. 
mentar uma estratégia de desenvolvimento industrial com foco na inovação e visão prospectiva de indústria, ciência e tecnologia.

Portanto, um esforço para dotar os quadros técnicos de capacitações mais adequadas a objetivos mais qualitativos da política industrial e tecnológica deve ser feito, concomitantemente à reforma das próprias instituições da área.

O quinto problema mencionado é a dificuldade de articulação que, juntamente com a coordenação, é um dos mais difíceis de resolver. Refere-se à articulação (1) intragoverno, entre instituições e entre instrumentos da política industrial e tecnológica e desta com outras políticas, e (2) do governo com o setor privado, principal protagonista da política industrial.

Esse problema surge não só por causa da extrema complexidade do conjunto de instituições de política industrial e tecnológica, como também pela excessiva burocratização do processo decisório, consequência do grande número de instâncias superiores que formam uma superestrutura de órgãos colegiados. Além da morosidade, essa superestrutura faz com que o processo decisório fique diluído devido a interdependências entre os vários órgãos, fragmentado devido a atribuições muito específicas, e sem um foco claro devido à falta de uma visão compartilhada, apesar da PITCE.

Um breve resumo dessa superestrutura de órgãos colegiados pode ser ilustrativo. Vinculados à Presidência da República estão: o Conselho de Desenvolvimento Econômico e Social, o Conselho de Governo e o Conselho Nacional de Desenvolvimento Industrial. Sob o Conselho de Governo estão a Câmara de Política Econômica, a Câmara de Comércio Exterior e a Câmara de Política de Desenvolvimento Econômico. Todos são compostos por ministros de Estado, representantes da iniciativa privada e de entidades da sociedade civil, e têm secretarias executivas ou comitês gestores integrados por membros do segundo escalão de governo. Têm funções normativas sobre políticas públicas que, direta ou indiretamente, afetam o desenvolvimento econômico e social de modo geral, e o desenvolvimento industrial e tecnológico em particular.

Sob essa superestrutura operam os ministérios com seus respectivos órgãos executivos, instrumentos e políticas específicas. A possibilidade de conflitos de competências, comportamentos autônomos e desarticulação das ações é muito grande. Em consequência, a captura das políticas por interesses privados ou burocráticos torna-se bastante provável. 
Por fim, a articulação com o setor privado. Pelas mesmas razões acima, essa articulação é muito precária. É claro que o papel das câmaras setoriais e dos fóruns de competitividade tem sido bastante positivo, mas falta uma articulação num nível superior, o que remete ao problema da coordenação.

O sexto e último problema é exatamente o da fragilidade do comando político e falha de coordenação do sistema institucional da política industrial e tecnológica. Esse é o maior problema e a questão central a ser resolvida. Por sua própria natureza, é tecnicamente muito complicado e politicamente muito delicado.

Tecnicamente implicaria dotar o sistema de uma instituição de comando, efetivamente coordenadora, possivelmente vinculada de forma direta ao presidente da República, mas com estrutura enxuta e poder de articular ministérios e órgãos públicos e estes com o setor privado. Implica também limitar a autonomia de instituições que hoje atuam segundo parâmetros e métricas próprias.

Politicamente a tarefa é extremamente delicada. Significa uma nova distribuição de poderes, com perdas e ganhos, redefinição de funções e atribuições, realinhamentos em torno de uma estratégia comum. Haverá resistência, tanto política quanto técnica e burocrática. Mas é indispensável para que haja uma coordenação efetiva, garantindo que o sistema opere de forma articulada e com uma visão compartilhada de estratégia de política industrial e tecnológica.

\section{Proposições para o Soerguimento e a Consolidação da Política Industrial - Uma Perspectiva de Longo Prazo}

Depois de tantos anos numa situação que vai da falta de legitimidade ao ostracismo, condenada por tantos males que produziu ou que lhe foram atribuídos, a política industrial possui, como tarefa mais importante (e urgente) a reconquista do seu direito de cidadania. Esta reconquista envolve (pelo menos) três dimensões, delicadas e laboriosas, mas plausíveis.

A primeira dimensão pertinente está ligada à formulação de objetivos que possam apresentar (imediatamente) ou desenvolver (ao longo do tempo) aderência a interesses mais amplos. Estes interesses podem ser beneficiários diretos porque as políticas lhes são direcionadas; ou meramente partidários, solidários com os seus propósitos, com as aspirações que a política pode ser capaz de despertar ou capitalizar para o leque dos seus apoios. Esta construção não está, evidentemente, assegurada $a$ priori. É possível, até mesmo provável, que qualquer determinada política possa ter beneficiários diretos, sem contudo conseguir legitimar-se de maneira mais ampla, 
perante outros segmentos (econômicos, sociais, correntes de opinião, regiões), seja pelo fato de não verem demandas específicas contempladas, seja pelo fato de terem que arcar com uma parcela dos custos que a política poderá criar. É razoável supor que uma política possa gerar descompassos entre custos e benefícios e é provável que os custos se tornem visíveis antes que os benefícios sejam perceptíveis, ou mesmo antes que sejam gerados. Por essa razão, para evitar as adversidades e os antagonismos gerados por um processo econômico, social e politicamente dinâmico como é este, a política industrial deveria buscar objetivos que possam ser amplamente compreendidos e assimilados como sendo de interesse geral. Dificilmente será possível reunir apoios e ampliar adesões se a formulação e a implementação da política não forem capazes de tocar as sensibilidades e as razões, o imaginário e o concreto, com casos que possam ser erigidos à condição de símbolos e exemplos. Nesse sentido, a reconquista da cidadania pela e para a política industrial demanda o exercício da responsabilidade, da construção de resultados com custos aceitáveis, e da possibilidade de que estes resultados sejam expressão de aspirações, anseios, objetivos.

A legitimação progressiva (e cumulativa) da política industrial é uma obra que ocorre no tempo, em períodos longos. Nada poderia solapar mais as bases de uma política industrial do que a descontinuidade dos seus objetivos e metas: antes mesmo que os seus objetivos sejam alcançados, são mudados, sem revisão precedida de análise criteriosa. Ora, para que os objetivos e as metas possam ser mantidos por período suficientemente longo para que possam ser alcançados, é necessário que sejam construídos com apoios amplos ou, idealmente, consensos pelo menos no plano interno, quer dizer, daqueles que defendem e devem sustentar a política industrial.

Isto demanda alguns esforços. Um deles consiste na consolidação - se possível, de forma articulada - das dimensões envolvidas pela política industrial. O plano setorial pode ser insuficiente, tanto quanto objetivos específicos das políticas de corte mais horizontal podem revelar-se limitados. A consolidação da política industrial demanda que a articulação dos planos (e dos objetivos) mais específicos possa constituir um leque de envolvimentos e apoios suficientemente amplo e consistente. Essa questão remete a uma antiga discussão entre duas perspectivas de política industrial que já produziram numerosos embates, quase sempre mais acalorados do que esclarecedores: políticas industriais horizontais versus (assim é colocado o debate) verticais.

Políticas industriais produzem intervenções na realidade, nas estruturas econômicas e no funcionamento dos mercados. De acordo com interpretações amplamente difundidas, intervenções horizontais são mais leves, intervenções verticais são mais pesadas. O principal elemento de uma intervenção vertical consiste em escolhas 
setoriais que no passado já se traduziram em derivadas extremas dessas escolhas, do tipo individualização de empresas favorecidas por determinados incentivos ou benefícios, e que são mencionadas como "a escolha (pelo Estado) dos vencedores (dos processos competitivos)".

O processo competitivo é sempre um processo de seleção, mas neste caso o Estado tornar-se-ia protagonista do processo seletivo. Ele não precisaria necessariamente subverter o processo seletivo do mercado porque de fato o leque de possibilidades é mais amplo. Esta modalidade de política vertical (setorial, com intervenção hiperdirigida) pode ir da ratificação da seleção pelo mercado à sua completa subversão, justificadas, ambas pelo mais variado leque de argumentos possíveis. O Estado, numa perspectiva de bem-estar ou de maximização de resultados, pode pretender acelerar o alcance do resultado final do processo competitivo, evitando os custos de processos demorados. A escolha de tecnologias e de padrões exemplifica bem este caso, embora a gama de possibilidades seja muito mais ampla.

Mas o Estado pode, igualmente, pretender modificar os resultados dos processos competitivos com relação àquele que seria produzido pela ação exclusiva das forças do mercado (e das demais instituições que influenciam esse processo, sem contudo estarem orientadas pelas diretrizes da política industrial). Este seria o caso, por exemplo, de duas trajetórias setoriais (ou empresariais) distintas, uma sustentável ambientalmente, e outra que implique custos crescentes à sociedade (externalidades negativas), a primeira mais frágil do que a segunda pelos custos em que (ainda) incorre, a segunda capturando benefícios de efeitos negativos gerados para além dos seus custos. As políticas setoriais são costumeiramente associadas a intervenções dirigidas, mas as políticas horizontais dificilmente podem ser neutras. $\mathrm{O}$ apoio diferenciado às pequenas e médias empresas poderia ser compreendido como uma política horizontal (e neutra), mas ele evidentemente irá excluir diversos setores, tipicamente de grandes empresas; e o mesmo poderia ser dito de vários outros objetivos considerados genéricos, horizontais e neutros.

As concepções vertical (setorial) e horizontal (neutra) da política industrial padecem, ambas, de um mesmo e grave defeito: a sua insuficiência. A política industrial não pode se colocar diante desta escolha, que restringe o seu alcance e ocasiona muitas de suas insuficiências. Se a política industrial se torna necessária, para construir trajetórias e conseguir objetivos que o jogo (complexo, mas insuficiente) das forças de mercado falha em alcançar, então ela deve reunir os instrumentos e os recursos para a consecução dos seus objetivos, e quanto mais adequados forem esses meios, tanto melhor. E não se trata, aqui, de confundir a força e o poderio dos instrumentos com a sua efetividade, o que constitui uma confusão frequente 
e um equívoco extremamente prejudicial, seja aos objetivos específicos da política industrial seja à sua legitimidade.

Um exemplo pode servir aos propósitos do entendimento deste ponto. A mais ampla disponibilidade de crédito (subsidiado ou não) e de recursos financeiros para a dimensão tecnológica da política industrial não apenas pode não ser necessária como pode ser deletéria para a consecução dos resultados almejados. O deslocamento acelerado da fronteira tecnológica pode beneficiar-se de uma construção coletivamente estruturada, onde as diversas competências sejam somadas e articuladas, viabilizando escolhas prévias por meio da convergência e da focalização dos esforços. A chamada pesquisa pré-competitiva pode produzir resultados muito mais consistentes em termos da definição de uma plataforma comum, amplamente compartilhada, sobre a qual assentam, depois, os desenvolvimentos específicos e as apostas dos diversos protagonistas de mercado. Numa primeira fase, por esforço coletivo, viabiliza-se um denominador comum, encurtando prazos e economizando recursos; numa segunda fase, de implementação e difusão, as empresas levam aos mercados as suas respectivas apostas específicas, adequadas às personalidades de cada empresa, coerentes com a sua base de recursos de produção (e de tecnologia) e às características dos seus "públicos-alvo". Evidentemente, a dificuldade maior desta solução superior não está na disponibilidade de recursos financeiros, que seriam muito menores, mas na articulação de atores e na mobilização das aptidões e competências necessárias, sobretudo em termos das coordenações minuciosas, laboriosas.

Num tal enfoque de política industrial, relega-se a um plano menor, quiçá abandonase, a ideia de que é necessário escolher entre abordagens horizontais ou verticais, objetivos genéricos ou escolhas setoriais. Uma política industrial só pode ser eficaz quando ela define objetivos à altura dos seus meios; quer dizer, os meios disponíveis condicionam de maneira incontornável os fins, os objetivos, as metas. E uma vez definido o seu escopo potencial, trata-se de verificar se os seus meios estão à altura; caso contrário, é necessário ampliar os seus meios... ou redefinir o seu alcance. Mais uma vez, é necessário enfatizar que o soerguimento das estruturas de produção, para que se tornem vetores de desenvolvimento econômico e social, só poderá contar com o auxílio da política industrial se esta for capaz de legitimar-se progressivamente, contando com os seus sucessos anteriores para legitimar os seus próximos passos.

Após o longo período de fracasso, deslegitimação e desconstrução da política industrial, a sua reinserção no debate público e a sua legitimação demandam sucessos que revertam efetivamente o processo. Este processo de reforço, de cumulatividade, 
deve portanto passar por objetivos menores, à altura dos meios disponíveis, construindo progressivamente um alcance maior.

A articulação das dimensões mais verticais com aquelas mais horizontais poderia efetivamente servir para dar base e lastro para o processo de reconstrução da política industrial. Esta articulação parece estar presente na política industrial quando ela, por exemplo, privilegia como setores a serem incentivados aqueles que fornecem aos demais instrumentos de mudança, de reforço das suas aptidões, de criação de novas competências. Quando assim ocorre, a política industrial de fato articula as dimensões vertical (os setores escolhidos para terem apoio, incentivo, fomento de forma diferenciada) e horizontal (os demais setores, que receberão os efeitos dinâmicos proporcionados pelos setores escolhidos).

No período recente, a política industrial brasileira (PITCE - Política Industrial, Tecnológica e de Comércio Exterior) definiu contornos que podem ser considerados coerentes com essa visão. Três dos quatro setores eleitos pela PITCE são precisamente geradores e difusores de progresso. De fato, nada melhor do que o setor de bens de capital para difundir, numa economia e num tecido industrial onde ainda preponderam inovações de processo recebidas de fora da empresa e do setor, inovações tecnológicas que propiciem incrementos de produtividade, reduções de custo e melhoria de qualidade. O mesmo pode ser dito, possivelmente com tão forte razão quanto e uma amplitude ainda maior, para o caso da escolha setorial software: ele gera e propaga mudanças e o faz sobre todas as atividades, incluindo a mais completa gama de serviços, como a educação, a saúde, a administração pública e privada. É possível que no longo prazo a aposta brasileira em semicondutores, um elemento básico do complexo eletrônico-informático, venha a produzir resultados importantes. Mas enquanto bens de capital e software são promessas que poderiam concretizar-se, o mesmo só poderá ocorrer com os semicondutores num prazo muito superior e, possivelmente, com retornos muito inferiores em relação aos investimentos durante um longo período. Por essa razão, enquanto os dois primeiros setores poderiam beneficiar-se de apoios amplos, e com isso contribuir para a reconstrução do espaço da política industrial, o mesmo dificilmente poderá ser dito da escolha setorial semicondutores. No caso da escolha setorial fármacos, isso se aplica com mais forte razão ainda. Não se trata de condenar a política industrial para o setor de fármacos, mas é necessário levar em conta que a condição primeira de sua legitimação consiste precisamente na sua articulação vertical-horizontal. Neste caso, ela envolve, de um lado, três entes ofertantes - as empresas nacionais, os grandes laboratórios internacionais com atividades industriais e comerciais no Brasil e a política de importações - e os entes que conformam a demanda - consumidores, poderes públicos e organizações de medicina coletiva. 
O caso da indústria farmacêutica é revelador de uma diferença importante entre as políticas industriais que foram extensivamente praticadas no passado e aquelas que podem ser consideradas plausíveis e promissoras no presente. Preocupada com a oferta, a política industrial deixou sempre de considerar ou relegou a plano secundário as considerações ligadas à demanda. A articulação entre oferta e demanda não apenas foi pouco considerada como muitas vezes conspirou contra a sustentabilidade da política. Isso permanece válido em grande medida. As políticas de saúde, do governo federal, dos governos estaduais e das localidades possuem, com forte razão, preocupações quanto aos custos dos tratamentos, enquanto a política industrial farmacêutica preocupa-se, principalmente, com o aumento da produção doméstica e da reconstrução das capacidades industriais das empresas. Quando a política industrial coloca uma forte ênfase na inovação, ela poderia, evidentemente, deslocar a política de oferta para este outro campo, combinando, assim, uma preocupação da estruturação da oferta com demandas que possivelmente não podem ser atendidas simplesmente com o leque de soluções existentes e o seu respectivo conjunto de preços. Por um processo ainda difícil de captar de forma abrangente e totalmente consistente, é possível dizer que tem havido uma mudança importante na estrutura e na dinâmica do setor farmacêutico no Brasil. Esta mudança foi iniciada nos governos anteriores, a partir de pelo menos duas mudanças institucionais: o fim da excepcionalidade patentária dos fármacos, com a lei de patentes (Lei n ${ }^{\circ}$ 9.279/1996), que regulou direitos e obrigações quanto à propriedade industrial, e a lei de medicamentos genéricos (Lei no 9.787/1999), que estabeleceu a criação do medicamento genérico e regulamentou a utilização de denominações genéricas nos produtos farmacêuticos. Ambas as medidas contribuíram para questionar de forma bastante importante o posicionamento competitivo dos principais protagonistas e reestruturar as configurações setoriais. $\mathrm{O}$ fim da exceção patentária reduziu significativamente as possibilidades de prosseguimento das estratégias competitivas das empresas nacionais que apoiavam as suas posições (quase) exclusivamente em suas estruturas comerciais, um ativo raro: sempre que uma nova empresa pretende entrar no mercado, ela relativiza os lucros brutos que poderia auferir com os custos de montar uma rede de vendas, optando frequentemente pelo recurso ao licenciamento ou à comercialização por terceiros possuidores de vantagens comerciais. Ademais, estes poderiam recorrer à via da importação paralela, minando as vantagens do produtor original. Assim, o ativo tecnológico e industrial tornou-se em grande medida tributário do ativo comercial. A lei de patentes estabeleceu uma nova condição entre as dimensões industrial-tecnológica, de um lado, e comercial, de outro. Levou, com isso, a que as empresas repensassem a importância da capacitação técnica, reforçada pelos genéricos, e dos produtos inovadores. A definição prioritária ensejada pela PITCE, em 2004, assim, inscreve-se neste quadro como uma continuidade, mesmo 
se involuntária. ${ }^{27}$ Pelo menos duas das instituições brasileiras vinculadas à política industrial alinharam-se - mesmo que muito parcialmente - a estes objetivos. De um lado, o BNDES (vinculado ao Ministério do Desenvolvimento) passou a financiar com taxas favorecidas os setores pertinentes, e o setor encarregado da gestão da carteira de empresas do setor farmacêutico contou com uma agilidade diferenciada. De outro lado, a FINEP (vinculada ao Ministério de Ciência e Tecnologia) enfatizou em suas operações a farmacêutica, para a qual lançou programas dedicados e ações específicas. Evidentemente, a amplitude, a intensidade e a velocidade deste processo ainda estão longe das necessidades, mas esse problema só poderá ser corrigido com um monitoramento fino e uma gestão cada vez mais minuciosa. Prosseguido esse esforço por mais um dois decênios, poderá a indústria farmacêutica brasileira alçar-se a um novo padrão de capacitação, de produção e de competição? Existem dúvidas fundadas sobre a prioridade que poderá ser conferida a esta política ao longo dos anos e, mais grave, sobre a própria continuidade. Mais uma vez, o básico da política industrial - continuidade nas suas grandes escolhas e trajetórias, com reavaliação e correções pontuais - está longe de assegurado. Mas é possível que a política industrial, com perseverança e rigor, possa realmente fazer diferença pelo deslocamento do patamar competitivo e a reconfiguração das estruturas e dos padrões competitivos.

A política para bens de capital e software poderia perseverar nesse esforço, mesmo que renovando (no específico) objetivos, programas, instrumentos e metas, e poderia fazê-lo por um período suficientemente longo para que resultados fossem alcançados. Que a política industrial possa servir para reforçar o crescimento industrial não deveria significar que o seu objetivo maior seja o do crescimento. Um crescimento extensivo, sem mudanças nas estruturas, nos padrões competitivos, nas trajetórias, poderá contribuir para agravar muitos dos problemas que recorrentemente assolaram o desenvolvimento brasileiro. $\mathrm{O}$ fato de que a China se tornou, para o mal e para o bem, uma gigantesca fonte fabril e manufatureira do mundo como um todo, só agrava ainda mais um fenômeno que, antes mesmo dessa presença chinesa e do seu Chinami ${ }^{28}$, era já suficientemente perturbador das trajetórias, tanto as brasileiras como as dos países em desenvolvimento com cadeias produtivas industriais em processo de estruturação, que foram todos severamente atingidos pela emergência das crises macroeconômicas dos anos 1980-90 e pelas mudanças estruturais do sistema industrial. Por isso, o objetivo de reforçar o desenvolvimento do tecido econômico e do sistema industrial em especial deveria ser mantido como objetivo em si, não meramente como força propulsora do crescimento. Direcionar

27 O documento oficial da política industrial brasileira, datado de 2003, não menciona qualquer destes elementos anteriores.

28 Expressão que designa a gigantesca onda chinesa (tsunami) que invade os mercados mundiais de produtos manufaturados. 
o crescimento, estruturar novas atividades e dotar as atividades existentes de novos padrões, contemporâneos, alicerçados em novas competências e na capacidade (dinâmica) de adquiri-las. Esta agenda não deveria ser subsumida à do puro e simples crescimento, inclusive porque este poderá ser alimentado por parâmetros macroeconômicos que se revelam marcados pela vaga chinesa de produção de manufaturas a baixo custo e com preços de mercado reduzidos (Figura 1).

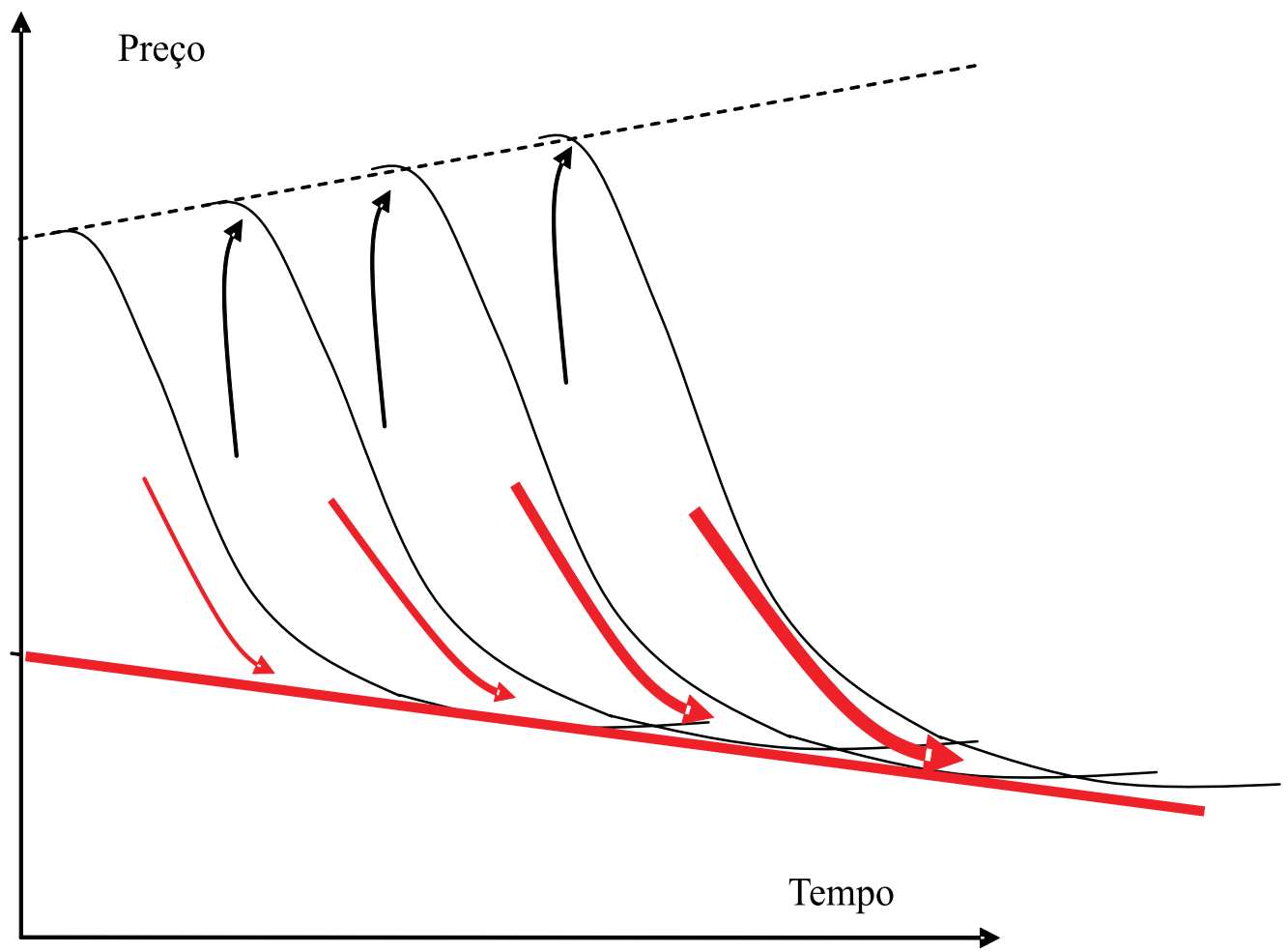

Figura 1 - Tendências Históricas dos Preços dos Produtos Industriais sob a Influência de Duas Forças Maiores: a Intensificação dos Esforços de Inovação e a Aceleração do Processo de Difusão das Inovações

Fonte: elaboração própria.

Este movimento ocorre lado a lado com uma força altista sobre o preço das principais commodities baseadas em recursos naturais, num movimento que poderá inverter de forma permanente as tendências históricas de longo prazo que se torna- 
ram muito pronunciadas com a crise da década de 1930 e as mudanças de preços relativos que as políticas econômicas foram levadas a produzir (Figura 2).
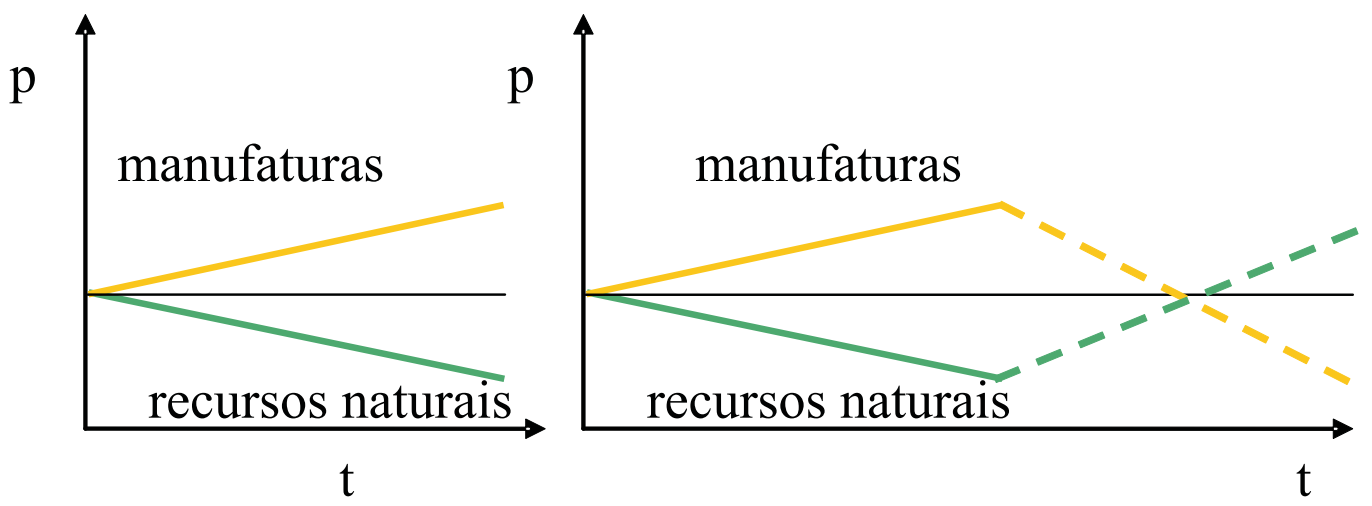

\section{Figura 2 - Tendências Históricas dos Preços das Matérias-Primas e dos Recursos Naturais Antes e Depois do Advento da China na Economia Mundial}

A articulação da política industrial com as políticas de crescimento, ou mesmo com o mero aproveitamento da bonança de crescimento ensejada pelo quadro internacional e pelo binômio China-EUA, deveria ensejar o deslocamento das trajetórias - hoje bastante favoráveis - para planos superiores. Por mais que a demanda chinesa desloque os preços das matérias-primas e dos recursos naturais para um patamar superior (Figura 2) e que a pressão da oferta chinesa a baixos custos produza o efeito inverso com os produtos industriais (Figura 1), que em muitos casos estão sendo "commoditizados" numa fase muito precoce do seu ciclo de vida, nada assegura que novas fontes de oferta não sejam mobilizadas, como revela a incorporação progressiva e rápida do continente africano à onda de prosperidade chinesa, ou que a demanda não possa rapidamente ser modificada por novas tendências do progresso tecnológico, como ocorreu em diferentes episódios altistas ao longo da história do capitalismo e do sistema econômico internacional.

\section{Conclusão e Proposições}

A implementação de qualquer política industrial é sempre uma tarefa árdua, complexa e delicada. Política industrial significa intervenção na realidade do mercado, tentando recriar essa realidade, para deslocar as trajetórias existentes para patamares superiores, para recriar as configurações existentes e dotá-las de dinâmicas novas e melhores. Essa mudança é por vezes entendida como uma tentativa de 
suprimir ou afrontar os mercados, mas deveria ser entendida mais como um processo de influenciar o seu funcionamento, sem, no entanto pretender substituir a sua lógica. Ela é não apenas poderosa e irremovível como pode, ademais, ser uma poderosa força da própria política industrial. A concorrência pode dar-se segundo parâmetros que apenas exploram as vantagens clássicas dos recursos existentes, ou pode desenvolver e explorar continuamente novas vantagens competitivas, criadas pelas forças do progresso técnico e da inovação, associadas a economias de escala e de escopo dinâmicas e a rendimentos crescentes. A melhor política industrial é aquela que consegue contribuir para este deslocamento, sem fraudar - e pelo contrário: utilizando - as forças de mercado e a concorrência, poderoso acelerador das mudanças. A política industrial não pode e não deve pretender substituir ou negar as forças poderosas do mercado e da concorrência, mas sim, compreendendo-as, lançar mão delas em prol dos seus propósitos e do desenvolvimento.

Se qualquer política industrial constitui um empreendimento difícil, pelo seu caráter laborioso, complexo e delicado, com mais forte razão isso ocorre num contexto em que os vícios e fracassos do passado apagaram inteiramente as conquistas históricas da política industrial, deixando-a estigmatizada e condenada a um prolongado ostracismo. Para que as novas políticas industriais possam reviver e reconquistar um espaço de cidadania, ao lado das políticas macroeconômicas e das demais políticas, é mister que elas cumpram um processo de legitimação; que passa pela gradual recomposição dos seus propósitos e resultados.

Nos países da América Latina, a implementação da política industrial tem revelado ser um calcanhar de Aquiles extremamente significante e perturbador. A definição de grandes objetivos ou a eleição de objetivos muito ambiciosos - e que dificilmente poderão ser alcançados em intervalos social e politicamente plausíveis - tornam-se uma fonte importante de fragilidades. As descontinuidades são não apenas uma possibilidade, como elas decorrem dos próprios sistemas de implementação - frágeis. Essa fragilidade contribui para propiciar reiteradas frustrações, que levam à revisão casuística, obedecendo a critérios pouco claros e frequentemente conjunturais.

Três tarefas são mais importantes nesse processo. A primeira diz respeito aos seus objetivos, que não devem ser excessivamente ambiciosos; pelo contrário, devem estar à altura dos meios disponíveis para o seu alcance. Ambições declaradas são promessas, e promessas frustradas são fontes de fragilidade, por isso devem ser evitadas. A segunda tarefa consiste na concepção de um sistema de implementação da política industrial que estabeleça claramente as etapas, os instrumentos, os recursos disponíveis, as incumbências de cada ente envolvido, a mobilização de competências existentes e o desenvolvimento de novas competências, a coordenação amiúde e sistemática. Esses são elementos decisivos, sem os quais qualquer política industrial 
pode soçobrar e deixar, atrás de si, um rastro de passivos onerosos do futuro. Para evitar esse risco, tão ameaçador, a terceira tarefa seria a de montar um sistema de acompanhamento da implementação da política, passo a passo. Estes três componentes deveriam, como método, incorporar-se a toda e qualquer política industrial. Nenhuma política industrial está totalmente protegida do risco de frustrações, mas é possível evitar muitos deles e minimizar outros, elevando as chances de sucesso, fortalecendo-as e dando-lhes longevidade.

\section{Referências}

ANDERSSON, T.; DAHLMAN, C. (Ed.). Korea and the knowledge-based economy. The World Bank: OECD Publishing, 2001.

BEFFA, J-L. Pour une nouvelle politique industriel. Paris, Secrétariat General du Gouvernement, Rapports Officiels, 2005.

BUENO, N. P. Um modelo de histerese institucional para a análise da política industrial brasileira. Pesquisa e Planejamento Econômico, v. 26, n. 2, p. 333-348, 1996.

CHANG, H-J. The political economy of industrial policy. London: Macmillan, 1994.

CHESNAIS, F. The French national system of innovation. In: Nelson, R. R. (Ed.). National Innovation Systems: a comparative analysis. Oxford: Oxford University Press, 1993, cap. 6.

CIMOLI, M.; DOSI, G.; NELSON, R.; STIGLITZ, J. Instituições e políticas moldando o desenvolvimento industrial: uma nota introdutória. Revista Brasileira de Inovação, v. 6, n.1, p. 55-85, 2007.

DOSI, G. Institutions and markets in a dynamic world. The Manchester School, v. 56, n. 2, p. 119-146, 1988.

.; KOGUT, B. National specificities and the context of change: the coevolution of organization and technology. In: KOGUT, B. (Ed.). Country competitiveness - technology and the organizing of work. Oxford: Oxford University Press, 1993, cap. 13.

JOHNSON, C. MITI and the Japanese miracle: the growth of industrial policy, 19251975. Tokyo: Charles E. Tuttle Co. Publishers, 1982.

. Introduction: the idea of industrial policy. In:

policy debate. San Francisco, CA: ICS Press, 1984. . (Ed.). The industrial

KIM, L. National system of industrial innovation: dynamics of capability building in Korea. In: NELSON, R. R. (Ed.). National innovation systems: a comparative analysis. Oxford: Oxford University Press, 1993, cap. 11. 
O sistema nacional de inovação sul-coreano. In: ; NELSON, R. (Org.). Tecnologia, aprendizado e inovação: as experiências das economias de industrialização recente. Campinas, SP: Editora da Unicamp, 2005.

METI - Ministry of Economy, Trade and Industry. Nakagawa report - toward a sustainable and competitive industrial structure. Tokyo: May 2004.

MOWERY, D. C.; ROSENBERG, N. The U. S. national system of innovation. In: NELSON, R. R. (Ed.). National innovation systems: a comparative analysis. Oxford: Oxford University Press, 1993, cap. 2.

MOWERY, D. C.; NELSON, R. R.; SAMPAT, B. N.; ZIEDONIS, A. A. Ivory tower and industrial innovation: university-industry technology transfer before and after the Bayh-Dole act in the United States. Stanford: Stanford University Press, 2004.

NELSON, R. R. (Ed.). National innovation systems: a comparative analysis. Oxford: Oxford University Press, 1993.

. What makes an economy productive and progressive? What are the needed institutions? LEM - Laboratory of Economics and Management, Sant'Anna School of Advanced Studies, Pisa, Italy, September 2006. (Working Paper Series 2006/24)

.; WINTER, S. G. An evolutionary theory of economic change. Cambridge, MS: Harvard University Press, 1982.

ODAGIRI, H.; GOTO, A. The Japanese system of innovation: past, present and future. In: NELSON, R. R. (Ed.). National innovation systems: a comparative analysis. Oxford: Oxford University Press, 1993, cap. 3.

PERES, W. El (lento) retorno de las políticas industriales en América Latina y El Caribe. Santiago de Chile: CEPAL, 2005. (Serie Desarrollo Productivo, n. 166).

POSSAS, M. L. Competitividade: fatores sistêmicos e política industrial - implicações para o Brasil. In: CASTRO, A. B.; POSSAS, M. L.; PROENÇA, A. (Org.). Estratégias empresariais na indústria brasileira: discutindo mudanças. Rio de Janeiro: Forense Universitária, 1996.

RODRIK, D. Industrial policy for the twenty-first century. Paper prepared for UNIDO, 2004. Available at: <www.ksg.harvard.edu/rodrik/>.

SUZIGAN, W.; VILLELA, A.V. Industrial policy in Brazil. Campinas: Unicamp/ Fapesp, 1997.

ZYSMAN, J. Governments, markets and growth. Ithaca, NY: Cornell University Press, 1983. 